\title{
HUBUNGAN BERMAIN GAME ONLINE DENGAN PRESTASI BELAJAR SISWA KELAS 4 DI MI DARUSSALAM JAMBANGAN SURABAYA
}

\author{
Aristina Halawa \\ STIKes William Booth Surabaya, Jalan Cimanuk No.20 Surabaya \\ Email: halawaaristina@yahoo.co.id
}

\begin{abstract}
ABSTRAK
Game online merupakan permainan modern yang sudah menjadi trend untuk masa sekarang dan semakin banyak peminatnya terutama pada anak-anak usia sekolah. Tujuan penelitian ini adalah untuk mengetahui hubungan bermain Game Online dengan hasil Belajar Siswa Pada Kelas 4 MI Darussalam Pagesangan Surabaya. Penelitian ini menggunakan desain cross sectional. Sampel pada penelitian ini adalah kelas IV a dan b yang semuanya bermain game online berjumlah 33 orang. Hasil penelitian menunjukkan bahwa hubungan bermain game online pada siswa kelas 4 di MI Darussalam Jambangan Surabaya sebagian besar adalah dalam tingkat sedang (3-4,5 jam). Pestasi belajar siswa kelas IV di MI Darussalam Jambangan Surabaya sebagian besar yaitu dengan prestasi belajar cukup sebanyak 16 (48,5\%). Ada hubungan antara bermain game online dengan prestasi belajar siswa kelas IV di MI Darussalam Jambangan Surabaya. Kesimpulan penelitian hipotesis dalam penelitian ini diterima karena cenderung anak yang mendapatkan prestasi belajar dalam kategori baik dan sangat baik bila intensitas bermain game online dalam tingkat rendah, sedangkan pada intensitas bermain game online di tingkat tinggi tidak ada anak yang mendapatkan prestasi belajar baik ataupun sangat baik.
\end{abstract}

Kata Kunci: Game Online, Hasil Belajar, Anak usia Sekolah

\begin{abstract}
Online gaming is a modern game that has become a trend for the present day and more and more devotees, especially in children of school age. The purpose of this study was to determine the relationship play Game Online with results Student in Class 4 MI Darussalam Pagesangan Surabaya. This study used cross sectional design. Samples are class IV $\mathrm{a}$ and $\mathrm{b}$ are all playing online games numbered 33 people. Results of the relationship play online games in Class 4 in MI Darussalam Jambangan Surabaya mostly in moderate ( 3 to 4.5 hours). Pestasi students of class $4 \mathrm{~d}$ MI Darussalam Jambangan Surabaya largely ie learning achievement quite as many as $16(48.5 \%)$. There is a correlation between playing online games with grade 4 student achievement in MI Darussalam Jambangan Surabaya. Conclusion study this hypothesis is accepted because it tends children get learning achievement in the category of good and very good when the intensity of online gaming in low levels, while the intensity of playing online games at a high level no children are getting the learning achievement of good or very good.
\end{abstract}

Keywords: Game Online, Learning Outcomes, Children in School Age 


\section{PENDAHULUAN}

Pada zaman sekarang ini semua media elektronik mengalami kemajuan yang sangat pesat, salah satunya adalah permainan elektronik yang sering dikenal dengan game online. Kejadian ini dapat kita lihat dari banyaknya pusat-pusat game yang bermunculan diberbagai kota baik kota besar maupun kota-kota kecil salah satunya yaitu kota Surabaya. Game online merupakan permainan modern yang sudah menjadi trend untuk masa sekarang dan semakin banyak peminatnya terutama pada anak-anak usia sekolah. Anak lebih sering dan rentan terhadap penggunaan permainan game online dari pada orang dewasa. Menurut (Hurlock, 2008) Anak sekolah dasar adalah anak dengan usia 6-12 tahun, pada usia ini anak lebih memahami dan masih suka bermain dan menyukai permainan yang mempunyai peraturan dan bernuansa persaingan sehingga membuat pemainnya akan bermain terus-menerus tanpa memperdulikan berapa lama waktu yang dipergunakan untuk mengalahkan lawannya. Menurut A.N (2011) game online akan mengurangi aktivitas positif yang seharusnya dijalani oleh anak pada usia perkembangan mereka. Anak yang mengalami ketergantungan pada aktivitas games, akan mempengaruhi motivasi belajarnya sehingga anak tersebut malas untuk belajar dan mengurangi waktu belajarnya. Jika waktu belajar anak kurang dan tidak ada konsentrasi saat belajar maka akan berdampak pada nilai anak. Hal ini dapat dilihat di MI Darusallam Jambangan Surabaya, saat penulis melakukan studi pendahuluan dengan bertanya kepada kepala sekolah serta bertanya langsung kepada siswa. Menurut kepala sekolah menjelaskan bahwa prestasi belajar kelas 4 terlihat mengalami penurunan seperti saat di kelas anak lebih suka bergurau dan mengobrol saat guru menjelaskan, disuruh mengerjakan malah anak bercanda dengan temannya. Selain itu mungkin karena faktor-faktor lain diluar sekolah atau di lingkungannya sehingga membuat anak kadang sulit berkonsentrasi saat di sekolah. Sedangkan saat penulis bertanya langsung ke 20 orang siswa kelas $4 \mathrm{a}$, dan $4 \mathrm{~b}$ tentang permainan game online, semua anak mengatakan suka bermain game online, 10 mengatakan bahwa saat bermain game online dari pulang sekolah hingga sore hari, bahkan ada yg lupa untuk makan dan beristirahat, sehingga malam harinya anak sudah lelah dan malas untuk belajar, 2 anak mengatakan bermain game online hingga 2-4 jam tanpa istirahat. Sedangkan 8 anak lainnya bermain game tetapi menyisihkan waktu untuk belajar.

Menurut hasil penelitian yang dilakukan oleh Weinstein (2010), menyimpulkan bahwa dari 1.178 pemuda Amerika Serikat usia 8-18 tahun memperlihatkan kecanduan game sebesar $8,5 \%$ yang mengarah pada perilaku patologis. Menurut penelitian Sanditaria, dkk (2011), penelitian yang dilakukan di Indonesia menyatakan bahwa dari hasil penelitian diketahui 71 orang responden anak usia sekolah didapatkan hasil penelitian yang menunjukan sebanyak $38 \%$ responden termasuk dalam kategori tidak adikasi dan $62 \%$ responden termasuk dalam kategori adikasi. Saat penulis melakukan studi pendahuluan di MI Darussalam jambangan Surabaya penulis bertanya pada wali kelas siswa kelas 4, bahwa nilai anak kelas 4 pada tahun ajaran 2016 diatas rata-rata $(\geq 70)$ sebesar 65\%, sedangkan tahun ajaran 2017 nilai rata-rata anak kelas 4 mengalami penurunan dibawah standart KKM (Kriteria Ketuntasan Minimal) rata-rata (60-69) hampir 59\%. Penulis melakukan wawancara kepada siswa kelas 4 dan masing-masing anak tersebut mengatakan suka bermain game online. Berdasarkan hasil wawancara tersebut dari 20 siswa 10 anak diantaranya kelas $4 \mathrm{a}$ dan $4 \mathrm{~b}$ mengatakan bahwa saat bermain game online dari pulang sekolah hingga sore hari, bahkan ada yg lupa untuk makan dan beristirahat, sehingga malam harinya anak sudah lelah dan malas untuk belajar, 2 anak mengatakan bermain game online hingga 2-4 jam tanpa istirahat. Sedangkan 8 anak lainnya bermain game tetapi menyisihkan waktu untuk belajar.

Menurut (Aji, 2012), game online merupakan suatu bentuk permainan yang dihubungkan melalui jaringan internet dan tidak terbatas pada perangkat yang digunakan. Game online juga bisa dimainkan melalui komputer, laptop, dan perangkat lainnya, asal gadget tersebut terhubung dengan jaringan internet. Dengan kecanggihan teknologi sekarang, game online sudah menjadi gaya hidup baru bagi beberapa orang disetiap kalangan umurnya, dangan banyaknya game center dapat menjadi 
candu bagi setiap pemain terutama pada anak usia sekolah. Didalam game tersebut terkandung story atau alur cerita yang biasanya terjalin dari berbagai masalah sehingga harus diselesaikan oleh individu yang membuat pemainnya tercandu untuk menyelesaikannya. Alur cerita setiap game dan tingkatan level permainan sangatlah panjang, salah satunya permainan game android COC (Clash of Clans) dan LGR (Line get Rich). Salah satu permainan ini bisa diselesaikan saat itu juga tetapi membuat ketagihan para pemain apabila bisa mengalahkan lawannya, hal inilah yang dapat menyebabkan seorang siswa lupa waktu. Masalah yang membuat seorang siswa apabila sudah kecanduan game online ketika sedang belajar di sekolah, namun pikiran mereka berada di game yang belum mereka tamatkan semalam. Selain itu, gangguan radiasi yang ditimbulkan dari penggunaan Personal Computer dan berbagai alat elektronik lain dapat mengganggu proses belajar mereka secara fisik seperti gangguan pada mata, kelelahan dan sebagainya. Adapun sebab yang membuat anak-anak kecanduan game online, salah satunya tantangan. Karena dalam setiap game ada tantangan, yang membuat pecandunya terus merasa tertantang. Sehingga pada akhirnya, anak yang kecanduan game akan merasa ketergantungan terus menerus dan tidak bisa lepas dari game. Menurut imanuel (2007) dampak yang yang ditimbulkan apabila anak kecanduan game online maka, anak akan menjadi malas belajar, anak menjadi lupa untuk mengerjakan PR, jadwal beribadahpun kadang dilalaikan oleh anak, pola makan terganggu, serta berpengaruhnya pada prestasi belajar. Selain itu kebanyakan bermain game online juga dapat mengganggu proses tumbuh kembang anak misalnya masalah sosialisasi, masalah komunikasi, mengikis empati, gangguan motorik, dan gangguan kesehatan seperti sakit kepala, nyeri leher, gangguan tidur, dan gangguan penglihatan. Menurut (Soeparman, 2009) Untuk mencegah seorang anak yang bermain game online tentu bukan pekerjaan mudah, fasilitas internet yang banyak tersedia di mana-mana salah satunya warung internet, menjadikan anak bisa mengakses internet dari mana saja. Permainan game online tidak selalu harus bermain di rumah melainkan anak bisa mencuri waktu sepulang sekolah dengan mengunjungi arena game online atau warung internet yang ada di sekitar sekolah mereka. Nursaid (2009) menjelaskan solusi yang tepat untuk mengatasi beberapa hal yang harus dilakukan orang tua agar anak dapat disiplin waktu khususnya dalam hal belajar yaitu orang tua dapat bekerjasama dengan guru di sekolah untuk turut memantau perkembangan belajar siswa, menjalin komunikasi informal agar seorang anak bisa terbuka pada orang tua, sehingga orang tua bisa memberikan pendidikan pada seorang anak tanpa sang anak merasa dihakimi, berikan waktu khusus bermain game online, dan tegasi anak untuk tidak bermain di luar waktu yang sudah disepakati. Ini menunjukkan bahwa sebagai orang tua tidak sekedar melarang, namun memberikan kelonggaran. Disisi lain orang tua mengajarkan anak untuk bertanggung jawab pada waktu dan tanggung jawab yang harus dilakukan oleh seorang anak yaitu belajar. Dengan belajar dan disenggangi oleh aktivitas bermain dengan batasan waktu akan membuat anak termotivasi untuk belajar. Sehingga besar kemungkinan dengan adanya disiplin waktu akan membuat anak lebih disiplin dalam belajar dan dapat meningkatkan prestasi belajar pada anak. Berdasarkan latar belakang diatas, peneliti tertarik untuk meneliti "Hubungan Bermain Game Online Dengan Prestasi Belajar Siswa Pada Kelas 4 di MI Darusallam Jambangan Surabaya".

\section{BAHAN DAN METODE}

Desain penelitian yang digunakan dalam penelitian ini adalah desain cross sectional, yakni jenis penelitian yang menekankan pengukuran atau observasi data variabel independen dan dependen hanya satu kali saja pada satu saat (Nursalam, 2016). Pada penelitian ini, peneliti akan mengkaji hubungan bermain game online dengan prestasi belajar anak.

Populasi pada penelitian ini adalah semua siswa pada kelas 4 yang bersekolah di MI Darussalam Pagesangan Surabaya, dengan jumlah 36 Siwa/Siswi dengan menggunakan tehnik sampling simple random sampling maka sampel pada penelitian ini adalah sebagian siswa pada kelas 4 yang bersekolah di MI Darussalam Pagesangan Surabaya sejumlah 33 siswa yang memenuhi kriteria penelitian. 
Variabel bebas (Independent) dalam penelitian ini adalah bermain game online. Variabel Dependent (terikat) dalam penelitian ini adalah prestasi belajar siswa pada kelas 4 yang bersekolah di MI Darussalam Pagesangan Surabaya.

Instrument pada penelitian ini yaitu dengan kuesioner untuk mengetahui bermain game online sedangkan instrumen untuk prestasi belajar siswa adalah nilai raport siswa.

Analisa data untuk hubungan bermain game online dengan prestasi belajar siswa pada kelas 4 yang bersekolah di MI Darussalam Pagesangan Surabaya menggunakan Uji Spearman.

\section{HASIL}

Data umum ini menggambarkan tentang karakteristik responden berdasarkan data demografi yang meliputi umur, jenis kelamin, jumlah saudara kandung, urutan anak, pendidikan orangtua, dan pekerjaan orang tua.

Tabel 1 Karakteristik responden berdasarkan umur di MI Darussalam jambangan Surabaya.

\begin{tabular}{cccc}
\hline No & Umur & $\begin{array}{c}\text { Jumlah } \\
\text { Responden }\end{array}$ & $\begin{array}{c}\text { Persentase } \\
(\%)\end{array}$ \\
\hline 1 & $<9$ tahun & 2 orang & $6,1 \%$ \\
2 & $9-10$ tahun & 22 orang & $66,7 \%$ \\
3 & $>10$ tahun & 9 orang & $27,3 \%$ \\
& Total & 33 orang & $100 \%$ \\
\hline
\end{tabular}

Berdasarkan data dari tabel 1 diatas didapatkan responden terbanyak berusia 9-10 tahun dengan jumlah responden 22 orang $(66,7 \%)$.

Tabel 2 Karakteristik responden berdasarkan jenis kelamin di MI Darussalam Jambangan Surabaya.

\begin{tabular}{cccc}
\hline No & $\begin{array}{c}\text { Jenis } \\
\text { kelamin }\end{array}$ & $\begin{array}{c}\text { Jumlah } \\
\text { Responden }\end{array}$ & $\begin{array}{c}\text { Persentase } \\
(\%)\end{array}$ \\
\hline 1 & Laki-laki & 22 orang & $66,7 \%$ \\
2 & Perempuan & 11 orang & $33,3 \%$ \\
& Total & 33 orang & $100 \%$ \\
\hline
\end{tabular}

Berdasarkan data dari tabel 2 diatas dapat diketahui responden terbanyak yaitu berjenis kelamin laki-laki dengan jumlah 22 orang $(66,7 \%)$.
Tabel 3 Karakteristik responden berdasarkan Jumlah Anak Dalam Keluarga di MI Darussalam Jambangan Surabaya.

\begin{tabular}{cccc}
\hline No & $\begin{array}{c}\text { Jumlah } \\
\text { Saudara } \\
\text { Kandung }\end{array}$ & Jumlah (n) & $\begin{array}{c}\text { Persentase } \\
(\%)\end{array}$ \\
\hline 1 & 1 & 9 orang & $27,3 \%$ \\
2 & 2 & 8 orang & $24,2 \%$ \\
3 & 3 & 9 orang & $27,3 \%$ \\
4 & 4 & 3 orang & $9,1 \%$ \\
5 & $>5$ & 4 orang & $12,1 \%$ \\
& Total & 33 orang & $100 \%$ \\
\hline
\end{tabular}

Berdasarkan data dari tabel 3 diatas diketahui responden yang memiliki saudara kandung tebanyak berjumlah 9 orang dengan jumlah 3 saudara dan anak pertama yaitu $(27,3 \%)$.

Tabel 4 Karakteristik responden berdasarkan posisi anak dalam keluarga di MI Darussalam Jambangan Surabaya.

\begin{tabular}{|c|c|c|c|}
\hline No & $\begin{array}{l}\text { Urutan } \\
\text { Anak }\end{array}$ & Jumlah (n) & $\begin{array}{c}\text { Persentase } \\
(\%)\end{array}$ \\
\hline 1 & Anak 1 & 14 orang & $42,4 \%$ \\
\hline 2 & Anak 2 & 10 orang & $30,3 \%$ \\
\hline 3 & Anak 3 & 7 orang & $21,2 \%$ \\
\hline \multirow[t]{2}{*}{4} & Anak 4 & 2 orang & $6,1 \%$ \\
\hline & Total & 33 orang & $100 \%$ \\
\hline
\end{tabular}

Tabel 5 Karakteristik responden berdasarkan Pendidikan Orang Tua di MI Darussalam Jambangan Surabaya.

\begin{tabular}{cccc}
\hline No & $\begin{array}{c}\text { Pendidikan } \\
\text { Orang Tua }\end{array}$ & $\begin{array}{c}\text { Jumlah } \\
(\mathrm{n})\end{array}$ & $\begin{array}{c}\text { Persentase } \\
(\%)\end{array}$ \\
\hline 1 & SD & 2 orang & $6,1 \%$ \\
2 & SMP & 9 orang & $27,3 \%$ \\
3 & SMA & 17 orang & $51,5 \%$ \\
4 & Perguruan & 5 orang & $15,2 \%$ \\
& Tinggi & & \\
& Total & 33 orang & $100 \%$ \\
\hline
\end{tabular}

Berdasarkan data dari tabel 5 diatas didapatkan Pendidikan Orang Tua responden terbanyak berjumlah 17 orang $(51,5 \%)$.

Tabel 6 Karakteristik responden berdasarkan Pekerjaan Orang Tua di MI Darussalam Jambangan Surabaya. 


\begin{tabular}{clcc}
\hline No & $\begin{array}{l}\text { Pendidikan } \\
\text { Orang Tua }\end{array}$ & $\begin{array}{c}\text { Jumlah } \\
(\mathrm{n})\end{array}$ & $\begin{array}{c}\text { Persentase } \\
(\%)\end{array}$ \\
\hline 1 & Pegawai & 22 orang & $66,7 \%$ \\
& Swasta & & \\
2 & Wiraswasta & 7 orang & $21,2 \%$ \\
3 & PNS & 3 orang & $9,1 \%$ \\
4 & Tidak & 1 orang & $3,0 \%$ \\
& Bekerja & & \\
& Total & 33 orang & $100 \%$ \\
\hline
\end{tabular}

Berdasarkan data dari tabel 6 diatas diketahui Pekerjaan Orang Tua responden terbanyak yaitu Pegawai Swasta sejumlah 22 orang $(66,7 \%)$.

Data Khusus

Data Khusus ini menghubungkan Bermain Game Online dengan Prestasi Belajar Siswa di MI Darussalam Jambangan Surabaya. Karakteristik responden berdasarkan Bermain Game Online dengan Prestasi Belajar Siswa di MI Darussalam Jambangan Surabaya.

Tabel 7 Karakteristik Bermain Game Online siswa kelas 4 di MI Darussalam Jambangan Surabaya.

\begin{tabular}{cccc}
\hline \multicolumn{4}{c}{ Intensitas } \\
No & $\begin{array}{c}\text { Bermain } \\
\text { Game } \\
\text { Online }\end{array}$ & $\begin{array}{c}\text { Jumlah } \\
\text { Responden }\end{array}$ & $\begin{array}{c}\text { Persentase } \\
(\%)\end{array}$ \\
\hline 1 & Rendah & 6 orang & $18,2 \%$ \\
2 & Sedang & 18 orang & $54,5 \%$ \\
3 & Tinggi & 9 orang & $27,3 \%$ \\
Total & 33 orang & $100 \%$ & \\
\hline
\end{tabular}

Berdasarkan tabel 7 diatas dapat diketahui sebagian besar intensitas bermain Game Online berada pada tingkat sedang dengan jumlah 18 orang $(54,5 \%)$.

Tabel 8 Karakteristik Hasil Belajar Siswa Kelas 4 di MI Darussalam Jambangan Surabaya.

\begin{tabular}{cccc}
\hline No & $\begin{array}{c}\text { Hasil } \\
\text { Belajar }\end{array}$ & $\begin{array}{c}\text { Jumlah } \\
\text { Responden }\end{array}$ & $\begin{array}{c}\text { Persentase } \\
(\%)\end{array}$ \\
\hline 1 & Kurang & 3 orang & $9,1 \%$ \\
2 & Cukup & 16 orang & $48,5 \%$ \\
3 & Baik & 12 orang & $36,4 \%$ \\
4 & Sangat & 2 orang & $6,1 \%$ \\
& Baik & & \\
& Total & 33 orang & $100 \%$ \\
\hline
\end{tabular}

Berdasarkan tabel 8 diatas dapat diketahui sebagian besar responden berprestasi belajar pada kategori cukup 16 orang (48,5\%).

Tabulasi Silang Bermaain Game Online Dengan Prestasi Belajar Siswa kelas 4 di MI Darussalam Jambangan Surabaya.

Tabel 9 Distribusi fekuensi responden bermain game online dengan prestasi belajar siswa kelas 4 di MI Darussalam Jambangan Surabaya.

\begin{tabular}{lccccc}
\hline $\begin{array}{l}\text { Prestasi } \\
\text { Belajar }\end{array}$ & & & & & \\
$\begin{array}{l}\text { Bermain } \\
\text { Game }\end{array}$ & Kurang & Cukup & Baik & $\begin{array}{c}\text { Sangat } \\
\text { Baik }\end{array}$ & Jumlah \\
Online & & & & & \\
\hline $\begin{array}{c}\text { Rendah } \\
\text { Sedang }\end{array}$ & $0(0 \%)$ & $0(0 \%)$ & $5(83 \%)$ & $1(17 \%)$ & $6(100 \%)$ \\
& $10(56 \%)$ & $7(39 \%)$ & $1(5 \%)$ & 18 \\
Tinggi & $3(33 \%)$ & $6(67 \%)$ & $0(0 \%)$ & $0(0 \%)$ & 9 \\
Total & 3 & 16 & 12 & 2 & $(100 \%)$ \\
Hasil uji statistic Spearman; $\mathrm{p}=0,000$ & & 33 \\
\hline
\end{tabular}

Berdasarkan tabel 9 Hasil dari tabulasi silang antara bermain Game Online dengan Prestasi Belajar pada siswa kelas 4 didapatkan, hasil bermain game online dengan intensitas bermain rendah dengan kategori nilai baik sebanyak $5(83 \%)$ dan intensitas bermain game online rendah dengan kategori nilai sangat baik sebanyak 1(17\%), intensitas bermain game online sedang dengan kategori nilai cukup sebanyak $10(56 \%)$, intensitas bermain game online sedang dengan nilai baik sebanyak $7(39 \%)$, dan intensitas bermain game online sedang dengan kategori nilai sangat baik sebanyak 1(5\%), intensitas bermain game online tinggi dengan kategori nilai kurang sebanyak $3(33 \%)$ dan intensitas bermain game online tinggi dengan kategori nilai cukup sebanyak $6(67 \%)$. Hasil uji statistik dengan spearman $\mathrm{p}=0,000$ dengan nilai kemaknaan $\mathrm{p}<0,005$ yang berarti $\mathrm{H} 1$ diterima yang artinya ada hubungan antara bermain game online dengan prestasi belajar siswa kelas 4 di MI Darussalam Jambangan Surabaya. 


\section{PEMBAHASAN}

Pada pembahasan ini penulis akan menguraikan hasil penelitian dalam bentuk pembahasan mengenai hubungan bermain game online dengan prestasi belajar siswa di MI Darussalam Jambangan Surabaya.

Intensitas Bermain Game Online pada siswa kelas 4 di MI Darussalam Jambangan Surabaya.

Berdasarkan Tabel 7 terlihat bahwa dari 33 responden, terdapat 6 responden $(18,2 \%)$ dengan intensitas bermain game online rendah, 18 responden $(54,5 \%)$ dengan intensitas bermain game online sedang, dan 9 responden $(27,3 \%)$ dengan intensitas bermain game online tinggi, sehingga dapat disimpulkan bahwa sebagian besar intensitas bemain game online yang biasa dilakukan anak sekolah dasar di MI Darussalam yaitu termasuk dalam tingkatan sedang, dengan durasi $3-4,5$ jam dalam sehari. Menurut Slameto (2003) terdapat beberapa karakteristik anak usia sekolah dasar, salah satu diantaranya adalah senang bermain. Dan pendapat tersebut juga didukung oleh pendapat yang disampaikan oleh Nakita (Gaol, 2012) bahwa bermain merupakan aktivitas atau suatu dorongan untuk menang yang ada dalam diri anak usia sekolah dan membuat mereka dapat berinteraksi dengan sesamanya. Game pada saat ini sudah menyebar dan sangat diminati hampir semua usia, begitu pula pada kehidupan anak usia sekolah. Anak yang masuk usia sekolah akan berusaha untuk mengikuti tren yang ada pada lingkungan pertemanannya, salah satunya adalah bermain game. Anak akan bersaing dengan temantemannya untuk menjadi yang paling hebat pada game yang dimainkan bersama. Dengan bermain lebih lama dari teman-temannya, anak akan menjadi lebih mahir dalam memainkan game tersebut dan berharap akan disegani di lingkungan pertemanan. Dan itu merupakan sebuah kebanggaan tersendiri bagi anak karena merasa bahwa dirinya telah dianggap hebat. Hal tersebut yang menyebabkan banyak anak usia sekolah di MI Darussalam bermain game online dalam kategori waktu sedang dengan durasi 3 4,5 jam.

Apabila dilihat bedasarkan hasil penelitian yang tertera pada tabel 3 karakteristik responden berdasarkan jenis kelamin didapatkan hasil bahwa dari 33 responden yang terbanyak adalah anak laki-laki sebanyak 22 orang $(33,3 \%)$. Menurut Lee et al (2007), jenis kelamin dapat mempengaruhi seseorang menjadi kecanduan terhadap game online dimana anak laki-laki lebih menyukai bermain game online dengan jenis yang memiliki variasi bermain dengan tingkat kesulitan dan adanya unsur kekerasan. Apabila dilihat dari tren game online yang beredar saat ini, banyak sekali ditemukan gamegame dengan jenis aksi atau kekerasan, dimana para pemainnya paling banyak diminati oleh anak laki-laki. Hal ini juga penulis temukan dari pengakuan beberapa siswa laki-laki bahwa mereka lebih suka bermain game tembaktembakan dan bertarung dengan musuh-musuh jahat seperti Pokemon, Naruto, dan Dragon Ball. Dengan bermain game online.

Selain jumlah anak didalam keluarga, posisi anak didalam keluarga juga dapat berpengaruh terhadap perhatian yang diberikan orangtua kepada anaknya. Bedasarkan tabel 4 responden yang terbanyak adalah anak pertama yaitu sebanyak 14 orang (42,4\%). Menurut Supandi (2011) pengalaman merupakan guru yang paling baik, terutama khususnya dalam mendidik anak. Anak pertama cenderung untuk lebih mendapatkan perhatian yang lebih dari orang tuanya. Orang tua yang mendapatkan anak pertama biasanya belum memiliki pengalaman yang baik dalam mendidik dan memperlakukan anak dengan tepat, sehingga mereka beranggapan bahwa membuat anak senang merupakan pencapaian utama orang tua kepada anak. Dan oleh karena itu, orang tua akan memberikan apa saja kepada anak agar anak mereka senang, salah satunya dengan memberikan anak gadget dan memperbolehkan anak bermain game, tanpa melihat pengaruh jangka panjang kedepannya terhadap kegiatan belajar anak dan prestasinya di sekolah.

\section{Prestasi Belajar pada siswa kelas 4 di MI Darussalam Jambangan Surabaya.}

Berdasarkan tabel 8 karakteristik responden berdasarkan prestasi belajar didapatkan hasil bahwa dari 33 responden sebagian besar adalah prestasi belajar kategori cukup yaitu 16 responden (48,5\%). Menurut Kurniawaty (2010) dalam rangka meningkatkan prestasi belajar anak ada beberapa hal yang harus dilakukan orangtua agar anak bisa 
berprestasi di sekolah yaitu peran dan dukungan guru di sekolah serta perhatian dari orangtua. Salah satu peran orangtua dalam memberikan perhatian kepada anaknya ialah dengan mendisiplinkan waktu dan memperhatikan perkembangan anaknya baik di sekolah maupun di rumah. Sedangkan prestasi belajar pada siswa di MI Darussalam Jambangan Surabaya sebagian besar dalam katogori cukup hal ini dikarenakan saat peneliti melakukan penelitian ketika dikelas saat guru menerangkan anak lebih mementingkan dirinya dan tidak mendengarkan guru berbicara atau menjelaskan, saat disuruh mengejakan tugas di sekolah anak-anak lebih memilih bercanda dengan temannya dan menunggu guru marah baru mulai mengerjakan, hal inilah yang menyebabkan anak kurang disiplin saat di rumah sehingga di sekolah mereka tidak fokus pada pelajaran. Anak yang kurang pengawasan dan perhatian dari orangtua baik di rumah maupun di sekolah juga dapat berpengaruh pada prestasi belajar anak. Bedasarkan teori dan fakta pada penelitian ini terdapat perbedaan dikarenakan kurangnya dukungan dan perhatian dari orangtua yang menyebabkan prestasi anak menjadi menurun, dan kurangnya pengawasan orangtua saat di sekolah yang menyebabkan anak malas untuk belajar saat disekolah.

Apabila dilihat dari tabel 6 mengenai karakteristik pekerjaan orang tua, ditemukan bahwa sebagian besar anak memiliki orang tua yang bekerja sebagai pegawai swasta, yaitu sebanyak 22 orang $(66,7 \%)$. Hal ini sesuai dengan teori yang disampaikan oleh Slameto (2003) bahwa salah satu faktor yang mempengaruhi prestasi belajar merupakan keluarga, yaitu orang tua. Orang tua dengan pekerjaan sebagai pegawai swasta, terikat dengan berbagai aturan yang ada di dalam perusahaan tempat orang tua bekerja. Perusahaan swasta yang dimiliki oleh suatu lembaga swasta juga kerap kali memberlakukan aturan jadwal yang ketat kepada karyawannya. Jadwal yang ketat ini membuat orang tua yang menjadi karyawan disana sulit untuk mengatur waktu untuk dapat bersama-sama dengan anak dan memberikan pengawasan dan perhatian terutama dalam hal belajar anak, sehingga hal ini menyebabkan anak menjadi merasa kurang diperhatikan dan membuat prestasinya menurun.

\section{Hubungan bermain game online dengan prestasi belajar sisiwa kelas 4 di MI Darussalam Jambangan Surabaya.}

Berdasarkan tabel 9 dapat dilihat hasil tabulasi silang bahwa responden yang memiliki intensitas bermain game online rendah memiliki prestasi belajarnya baik sebanyak 5 orang $(83 \%)$ dan sangat baik sebanyak 1 orang $(17 \%)$, sedangkan yang memiliki intensitas bermain game online tinggi prestasi belajarnya cukup sebanyak 6 orang $(67 \%)$ dan kurang sebanyak 3 orang (33\%). Pada hasil statistik dengan menggunakan Uji Spearman diperoleh yaitu signifikan sebesar 0,000 sehingga $\mathrm{p}<0,05$ maka H1 diterima yang artinya ada hubungan antara bermain game online dengan prestasi belajar siswa kelas 4 di MI Darussalam Jambangan Surabaya. Hal ini dapat dijelaskan oleh ungkapkan Santrock (2010) yang berpendapat bahwa sebenarnya anak yang sedang dalam fase remaja awal (9-12 tahun) dapat memahami bahwa tindakan yang dilakukan pada saat ini dapat mempengaruhi masa yang akan datang, dengan demikian anak mampu mempekirakan konsekuensi dari tindakannya. Hal ini juga didukung oleh pendapat Gentile (Malahayati, 2012) bahwa sebagian besar anak yang bermain game melakukannya karena berusaha untuk lari dari masalah yang sedang dialami. Proses belajar dan sosialisasi anak usia sekolah tidak jarang juga memiliki masalah-masalah yang dapat terjadi dalam lingkungan sekolahnya. Anak yang memiliki masalah sosial dengan temantemannya, maupun masalah pelajaran yang susah dimengerti, akan membuat anak lari dan mencari jalan keluar yang lebih mudah lewat game. Karakter game yang apabila gugur dapat kembali mengulang hingga selesai menjadi salah satu hal yang membuat anak senang dalam bermain game, sehingga anak terlarut-larut dalam game tersebut dan lupa akan kewajibannya untuk belajar. Aktivitas belajar anak yang kemudian terlupakan ini akan membuat anak mengalami penurunan minat belajar di sekolah yang akan berlanjut pada menurunnya prestasi belajar anak yang ditinjau dari nilai hasil belajar anak.

Bedasarkan hasil penelitian yang tertera pada tabel 4 karakteristik responden berdasarkan jumlah anak dalam keluarga, didapatkan hasil 
bahwa dari 33 responden, mayoritas anak yang memiliki saudara kandung 3 orang yaitu sebanyak 9 orang (27,3\%). Menurut Djamarah (2008) jumlah anak yang banyak biasanya kurang pengawasan dari orangtua atau dapat juga karena pemberian kasih sayang, atau perhatian orangtua yang tidak sama. Jumlah anak yang banyak dalam keluarga, juga mempengaruhi perhatian dan kontrol orang tua dalam keluarga. Banyaknya masalah dan urusan yang harus dikerjakan orang tua membuat perhatian yang diberikan kepada anak-anaknya menjadi berkurang. Orang tua akan memilih untuk memberikan anak gadget dan media elektronik lain yang dapat membuat anak sibuk dengan dirinya dan tidak meminta banyak hal dari orang tua termasuk perhatian. Hal ini menyebabkan anak menjadi mudah kecanduan untuk bermain game online dan memiliki intensitas bermain yang cukup lama. Hal ini menyebabkan anak juga menjadi berkurang aktivitas belajarnya di rumah, sehingga di sekolah prestasi anak menjadi tidak maksimal bahkan mengalami penurunan prestasi belajar di sekolah.

\section{SIMPULAN}

Hubungan bermain game online pada siswa kelas 4 di MI Darussalam Jambangan Surabaya sebagian besar adalah dalam tingkat sedang

Pestasi belajar siswa kelas 4 d $\mathrm{MI}$ Darussalam Jambangan Surabaya sebagian besar yaitu dengan prestasi belajar cukup sebanyak 16 $(48,5 \%)$.

Terdapat hubungan bermain game online dengan prestasi belajar siswa kelas 4 di MI Darussalam Jambangan Surabaya.

\section{SARAN}

Diharapkan untuk para guru dan kepala sekolah lebih meningkatkan lagi kerja sama dengan para orang tua dengan cara mengadakan pertemuan dengan orang tua pada saat awal semester ataupun pada saat pengambilan raport di akhir semester untuk memantau perkembangan dan prestasi belajar anak-anak di sekolah guna memperoleh hasil yang memuaskan di bidang pendidikan dan bagi orangtua, diharapkan dapat mengontrol dan memantau anak-anak yang sudah kecanduan game online dengan membatasi waktu bermain game, dan tidak memperbolehkannya untuk bermain game online sebelum mereka belajar atau menyelesaikan tugas-tugas dari sekolah. Orangtua lebih selektif dalam mencarikan mainan buat anak-anaknya. Sebisa mungkin permainan yang mempunyai unsur edukatif.

Diharapkan penelitian ini dapat digunakan sebagai acuan dalam memberikan pendidikan kesehatan kepada masyarakat tentang bahaya atau dampak bermain game online pada anakanak.

\section{DAFTAR PUSTAKA}

Amirullah. 2009. Bahaya bermain game. Jakarta: EGC

Antony. 2003. Pengertian game dan jenisjenisnya. Jakarta : PT. Rajagrafindo Persada

Gunarsa, S.D, \& Gunarsa, Y.S.D. 2006. Psikologi Perkembangan Anak dan Remaja. Jakarta : PT BPK Gunung Mulia.

Hurlock, E.B. 1999. Psilcologi Perkembangan (Suatu Pendelcatan Sepanjang Rentang Kehidupan). Alih Bahasa oleh 1stiwidayati \& Zarkasih. Jakarta : Erlangga

Ilyas. 2008. Fungsi dan Pengukuran Prestasi Belajar. Yogyakarta : Pustaka Belajar.

Kurniawati, Y. 2010. Jurnal Hubungan Bermain Game Online dengan prestasi belajar. Semarang: fakultas Universitas Katolik Soegijapranata. diakses pada tanggal 15 January 2018 pukul 20.10 wib dari

file:///C:/Users/kykye/Downloads/1078721518-1-PB\%20(2).pdf

Lee, et al. 2007. Leaving a neverEnding Game: Quitting MMORPGs and Online Gaming Addiction. Jakarta : Department of Sociology of National.

Malahayati, D. 2012. Kebiasaan Bermain Vidio Game dengan Tingkat Motivasi Belajar Pada Anak Usia sekolah. Depok : Fakultas Ilmu Keperawatan.

Nursalam. 2013. Konsep dan Penerapan Metodologi Penelitian Ilmu

Keperawatan. Jakarta: Salemba Medika

Oemar Hamalik. 2007. Dasar-dasar Pengembangan Kurikulum. Bandung : PT Remaja Rosda Karya. 
Park, Chung-Hoon, and Young-Gul Kim. 2006. "The Effect of Information Satisfaction and Relational Benefit on Consumers Online Site Commitmennts". Journal of Electronic Commerce in Organizations, Vol. 4, No. 1, Page 70 - 90.

Slameto. 2003. Belajar dan Faktor-Faktor yang Mempengaruhinya. Jakarta : PT Rineka Cipta.

Syah, M. 2006. Psikologi Belajar. Jakarta : Raja Grafindo Persada.

Syaiful Bahri Djamarah. 2008. Psikologi Belajar. Jakarta : Rineka Cipta 